\title{
Student Perspectives on Language and Culture Teaching in EFL: Implications for Intercultural Approach
}

\author{
Kai Li LIU \\ Language Center, Soochow University \\ No.70, Linhsi Road, Shihlin District, Taipei City 111, Taiwan \\ Tel: 886-2-2881-9471Ｅ-mail:liuk1@scu.edu.tw
}

Received: Jan. 25, 2019

Accepted: April 25, 2019

Published: May 1, 2019

doi:10.5296/jse.v9i2.14653

URL: https://doi.org/10.5296/jse.v9i2.14653

\begin{abstract}
Globalization has led to the need for incorporating world cultures into foreign language curricula to develop students' intercultural communicative competence. As a result, intercultural approaches as well as intercultural communicative competence have been widely studied. While there are a number of studies discussing this issue from the perspectives of teachers, the literature finds few studies regarding students' perceptions. Therefore, the question of whether there are any gaps between teachers' and students' perceptions remains unanswered. To help answer this question, this study conducted a survey exploring university students' perceptions of culture learning and teaching in the English classroom by using a combination of quantitative and qualitative methods. Based on the results of a questionnaire and interviews, this study found the practice and the materials used in EFL teaching might not satisfy the requirements of leaners as users of English as a lingua franca (ELF) for intercultural communication. Thus further research regarding effective teaching methods is needed.
\end{abstract}

Keywords: culture teaching and learning, EFL, intercultural communicative competence, intercultural approach, English as lingua franca (ELF) 


\section{Introduction}

There is a growing belief that culture teaching and language teaching are inseparable, and that culture should always be integrated into language learning context in foreign language education (Nault, 2006). This belief is difficult to argue against as there is mounting evidence to show that culture learning contributes to the success of language learning (Byram \& Morgan,1994; Chung \& Chow, 2004; Ho, 1998; Lin, 2004; Sung \& Chen, 2014; Tavares \& Cavalcanti,1996). It is also often noted that the necessity to integrate culture learning into language learning is becoming even more apparent under the influence of globalization. Accordingly, many scholars around the world advocated for the integration of culture into ESL/EFL teaching to accommodate the use of English as a means of international and intercultural communication (Alptekin, 2002; Byram, 1997; Chao, 2009; Ke, 2010). This implies the focus of language learning is shifting from developing one's communicative competence to developing intercultural communicative competence.

The development of intercultural communicative competence has received a lot of attention worldwide. Educators, teachers and researchers have gone to some lengths to promote the importance of the cultural dimension in English learning and explore effective teaching methods to help language learners to become interculturally competent. In the literature, many studies (Cheng, 2006; Cheng, 2012; Lai, 2006; Stapleton, 2000; Sung \&Chen, 2009; Wu, 2015; Yang, 2004; Yo, 2007; Young \& Sachdev, 2011) discuss this issue from teachers' perspectives. Teachers' beliefs and practices in the classrooms are explored with the implication that teachers' beliefs directly affect their perceptions of both teaching and learning in the classroom (Clark \& Peterson, 1986; Clark \& Yinger, 1987). However, studies on students' views are relatively rare. As a result, cultural instruction has become a topic about which much has been said by experts while little has been heard from learners (Chang, 2004). This has prompted the author of this paper to ponder on the following questions: How do students perceive language and culture; To what extent are they aware of English's role as a lingua franca; To what extent do they receive cultural instruction in the classroom; and what do they think of the instruction and materials used?

With a need to answer these questions, the author conducted a survey exploring university students' perceptions of culture learning and teaching in English language classrooms in one comprehensive university located in Northern Taiwan by using a combination of quantitative and qualitative methods, in an attempt to understand student perspectives of the current English teaching practice. This survey of culture and language teaching from students' perspectives is thus an attempt to understand what is happening in the classroom, to what extent the goal of using intercultural approach has been practiced and what aspects of this need improvement.

It is hoped the answers to these research questions in this study can make a significant contribution to the success of culture learning and teaching under the English as Lingua Franca (ELF) paradigm and empower students' voices in their education. It is expected that exploring students' perceptions will contribute to a better understanding of learners' attitudes towards culture learning in EFL teaching and identifying the gaps between experts' and 
learners' views. This understanding will allow pedagogical suggestions for more successful and effective cultural instruction to be made to textbook writers, curriculum designers and teachers.

\section{Literature Review}

\subsection{The role of culture in English language pedagogy}

Language and culture are closely linked. As Brown (2001) states, whenever you teach a language, you also teach a complex system of cultural values, ways of thinking, customs and behaviors. This close relationship between language and culture suggests that a language cannot be fully learned without some degree of understanding of the cultural context, which is also reinforced with a lot of evidence showing that culture learning can make a contribution to the success of communication and language learning (Byram \& Morgan,1994; Chung \& Chow, 2004; Ho, 1998; Lin, 2004; Sung \& Chen, 2014; Tavares \& Cavalcanti,1996).

Garrett-Rucks (2016) reviews a range of pedagogical perspectives of how culture has been situated within foreign language instruction from the grammar-translation method to the communicative language approach leading to intercultural communicative competence (ICC) and literacy-based approaches. Under the old grammar-translation method, notions of the target culture were mainly defined by "Big C" culture, referring to the products of a country or sociocultural achievements in the arts. In the late1960s, when the audio-lingual method emerged, discussions of culture began to promote the inclusion of "little c" culture, signifying people's life styles and behaviors, such as daily activities, personal values, customs, lifestyles, attitudes and traditions.

During the 1970s and 1980s, a modern approach, Communicative Language Teaching (CLT), placed a greater emphasis on the oral use of the language for meaningful communication to develop learners' communicative competence. CLT proposes to situate foreign language teaching in a clearly defined social and cultural context corresponding to the socio-linguistic viewpoint that language is generally influenced by culture, the society, economics, and the people who use it. Thus, the importance of cultural understanding has been widely recognized and its incorporation into language teaching has continued to increase.

However, with globalization impacting on English language education, the role of the English language has shifted from a medium of communicating primarily with native speakers to a more general medium of communication with both native and non-native speakers. This change has led to discussions of English as a Lingua Franca (ELF) and intercultural competence. As Byram (1997) argues, defining communicative competence mainly in terms of sociolinguistic norms of a particular social group or on a native speaker model basis seems to be rather narrow a view from the perspective of intercultural communication. This is because such a definition does not take cross-cultural communication into consideration. Barnes-Karol and Broner (2010) also noted that the learning of culture in CLT emphasizes products and practices with disregard for perspectives. Due to the increased criticism of CLT, discussions have shifted from culture-specific to culture-general models of intercultural 
competence in the 1990s.

\subsection{English teaching in the era of ELF}

This new role of English as a Lingua Franca (ELF) calls for three changes in English language teaching.

\subsubsection{From communicative competence to intercultural competence}

Rather than communicative competence, intercultural competence has been recognized as an essential skill in the globalized world (Alptekin, 2002; Byram, 1997; Chao, 2009; Ke, 2010). Hence, learning to deal with different cultures effectively requires cultural awareness, communicative competence, personal attitudes like empathy and flexibility, self-awareness and understanding of others' values, norms, and beliefs (Byram, 2009). To develop such ability, a new pedagogic model is urgently needed to accommodate the case of English as a means of international and intercultural communication.

\subsubsection{Implementing an intercultural approach}

An intercultural approach has been widely proposed to train learners to be ELF users. Liddicoat's perspective on intercultural exploration is that source and target cultures are equal and learners learn cultures through the language they are learning (Liddicoat, 2011). He advises some teaching points for teachers to adopt or adapt to help students develop abilities for intercultural exploration. These teaching skills include a) involve students in a process of noticing, reflecting, and interacting; b) construct source and target culture; c) view instances of language use as experiences of culture and opportunities for culture learning; d) focus on the capabilities required for on-going learning about cultures through experiences of languages; and e) encourage the inclusion of multiple perspectives.

\subsubsection{Diverse cultural contents in ELF}

The focus of culture learning has been shifted from specific English-speaking cultures to intercultural teaching as a goal to develop intercultural competence of English learners (Sercu, 2006). It is suggested that a diversity of culture, as well as non-mainstream cultures should be included in ELT instruction. This would help increase learners' interest by exposing them to a variety of cultures, rather than constantly imposing only one culture upon them. It would also help avoid the fear of assimilation into a specific culture, and help them show respect to different cultures. McKay $(2002,2012)$ identifies three types of cultural materials to be used: target culture materials, learners' own culture materials and international target culture materials, emphasizing that students' own culture should be integrated into culture learning. Kramsch (1993) also states that teaching should include "a reflection both on the target and on the native culture." Robinson (1988) also suggests, "cultural understanding involves a synthesis between the learner's home culture, the target cultural input and the learner as an individual."

\subsection{Studies on perceptions of culture teaching of students in Taiwan}

Among local studies pertaining to intercultural communicative competence, there are some 
that have tapped into students' opinions on culture learning. Chang (2004), for example, surveyed 120 senior high school students' perceptions of culture, the relationship of culture and language, cultural instruction received in the English class, and their knowledge of native and target culture. Following the valuable insights from Chang (2004), Chen (2011) investigated 1050 senior high school students' perceptions of culture teaching. The results show that in general, students held positive attitudes towards culture learning. They recognized the close relationship between language and culture, and they considered culture learning beneficial to their English learning. While they were generally pleased with their English teachers' cultural instruction, they were less satisfied with the cultural content presented in current English textbooks. As for their preferences of cultural instruction in English class, authentic materials, such as films, songs, and pictures, were the most favored materials, while games and interaction with foreigners were the most popular activities. Things related to daily life were the favorite topics, and true/false and multiple choice questions were the favorite methods of assessment of culture learning. Students also indicated that English-speaking cultures should not be the only cultures introduced in the English class. Students' gender, along with English proficiency, exposure to English media/foreign culture, and future goals were found to have played important roles in shaping their perceptions of culture learning.

In higher education, Sung and Chen (2008) conducted a study on the viewpoints of certain university students in Taiwan, showing that the students held positive attitudes towards the incorporation of English-speaking cultures into their English learning. In addition, Tsai (2016) interviewed 12 university students in Taiwan to explore students' views on the cultural dimension in EFL teaching. The study found that all of the participants show interest in culture learning, but considered there to be a lack of the cultural dimension in EFL teaching because of the focus on linguistic components, the test-oriented learning environment, the lack of interest in other countries, teachers' limited knowledge of teaching culture, and the influence of parents. The factor relating to teachers lacking the knowledge of how to teach culture is also found in many studies on the perceptions of teachers (Cheng, 2006; Cheng, 2012; Lai, 2006; Stapleton, 2000; Sung \&Chen, 2009; Wu, 2015; Yang, 2004; Yo, 2007; Young \& Sachdev, 2011).

The rise of the recognition of English as a lingua franca is calling for new and more effective ways to include cultural content into English classes. Therefore, different from the previous studies, this study explored university learners' opinions regarding culture teaching and learning with a focus on the perspective of ELF.

\section{Method}

\subsection{Participants}

Participants were 210 non-English majors who were taking the course Freshman English at the university where the study was conducted. Freshman English is a 2-credit required course and students were placed into three levels: high (L1), mid (L2) and low (L3) based on their scores on the English subject test in the National College Entrance Examination. Two classes from each level were randomly selected. A total of 250 questionnaires were distributed to six 
classes. There were 210 students completing the questionnaires providing a return rate of $84 \%$. There were 13 students participating in a semi-structured interview. Among them, there were four students from high-level classes (L1S1-L1S4), four from mid-level classes (L2S1-L2S4), and five from low-level classes (L3S1-L3S5). The details regarding gender, major area of study, English proficiency level, interviewees, and interviewee gender are displayed in Table 1.

Table 1. Demographic information

\begin{tabular}{|c|c|c|c|c|c|c|}
\hline Gender & $\mathbf{M}$ & $\mathbf{F}$ & & & & $\mathbf{N}$ \\
\hline & 73 & 137 & & & & 210 \\
\hline \multirow[t]{2}{*}{ Study } & Humanities & Language & Business & Law & Science & \\
\hline & 47 & 42 & 90 & 13 & 18 & 210 \\
\hline \multirow[t]{2}{*}{ Year } & Freshman & Sophomore & Junior & Senior & & \\
\hline & 210 & 0 & 0 & 0 & & 210 \\
\hline \multirow[t]{2}{*}{ Class Level } & High(L1) & Mid (L2) & $\operatorname{Low}(\mathbf{L 3})$ & & & \\
\hline & 67 & 74 & 69 & & & 210 \\
\hline Interviewee & 4 & 4 & 5 & & & 13 \\
\hline Interviewee Gender & 4 & 9 & & & & 13 \\
\hline Interviewee Study & 6 & 3 & 3 & 0 & 1 & 13 \\
\hline
\end{tabular}

\subsection{Data Collection}

The researcher constructed a questionnaire to collect the primary data to answer the research question. After carrying out the questionnaire survey, a further invitation was made to recruit volunteers who would like to participate in semi-structured interviews in the hope of gaining more in-depth insights to supplement the findings of the questionnaire survey.

\subsubsection{Construction of the questionnaire}

Based on the literature review pertaining to culture and language, cultural instruction, previous studies on students' perceptions of culture learning, studies on cultural content in textbooks and the purpose of this study, a questionnaire was constructed. It was then modified based on the suggestions from one translator and two experts on culture and English language learning. Finally, it was put to the test in a pilot study in September 2017. Some confusion was found concerning some of the questions during the pilot study, thus some final changes were made before the formal survey was carried out.

\subsubsection{Content of the questionnaire}

The final version of the questionnaire consists of 2 sections: I) the participants' demographic information, and II) language and culture teaching. 32 questions in Section II were categorized into five themes: (1) perceptions of language and culture, (2) ELF perspective, (3) current cultural instruction in the classroom, (4) perceptions of cultural instruction received, and (5) perceptions of cultural content in textbooks. Some questions regarding language and culture, cultural instruction and cultural contents were adopted from Chen's study (2011). The 
researcher added questions regarding attitude toward to native-like English and current classroom practice. Although the questions in Section II are not statistically validated, they serve the purpose of eliciting participants' perceptions of language and culture and the cultural instruction they received. The detailed layout of the questionnaire is shown in Table 2.

Table 2. Layout of the questionnaire

\begin{tabular}{|c|c|c|c|}
\hline Sections & Themes & Items & \\
\hline \multirow{11}{*}{$\begin{array}{l}\text { I. Demographic } \\
\text { information }\end{array}$} & University & University & 1 \\
\hline & Gender & Gender & 2 \\
\hline & \multirow[t]{3}{*}{ Academic status } & School Year & 3 \\
\hline & & Major & 4 \\
\hline & & School & 5 \\
\hline & \multirow{3}{*}{$\begin{array}{l}\text { Foreign language } \\
\text { learning }\end{array}$} & Years of English learning & 6 \\
\hline & & Other foreign language learning & 7 \\
\hline & & Contact with foreign language-learning resources & 8 \\
\hline & \multirow{3}{*}{$\begin{array}{l}\text { Direct experience of } \\
\text { foreign cultures }\end{array}$} & Social contact with foreigners & 9 \\
\hline & & Being abroad & 10 \\
\hline & & Culture shock & 11 \\
\hline \multirow{19}{*}{$\begin{array}{l}\text { II. } \\
\text { Language and } \\
\text { Culture Teaching }\end{array}$} & \multirow{4}{*}{$\begin{array}{l}\text { (1) Perceptions of } \\
\text { language and } \\
\text { culture }\end{array}$} & Interest in culture & 1 \\
\hline & & Relationship of language and culture & $2-3$ \\
\hline & & Goals for culture learning & $4-7$ \\
\hline & & Perceived benefits of culture learning & $8-10$ \\
\hline & \multirow{4}{*}{$\begin{array}{l}\text { (2) Self-awareness } \\
\text { of ELF }\end{array}$} & Standard English & \multirow[t]{4}{*}{$11-14$} \\
\hline & & Native-speaking cultures & \\
\hline & & Own culture & \\
\hline & & Foreign culture & \\
\hline & \multirow{7}{*}{$\begin{array}{l}\text { (3) Current cultural } \\
\text { instruction in } \\
\text { the classroom }\end{array}$} & Teacher belief & 15 \\
\hline & & Approaches or activities & $16-17$ \\
\hline & & Cultural materials & 18 \\
\hline & & Assessment & 19 \\
\hline & & Local culture & 20 \\
\hline & & English-speaking culture & 21 \\
\hline & & Foreign culture & 22 \\
\hline & \multirow{4}{*}{$\begin{array}{l}\text { (4) Perceptions of } \\
\text { cultural } \\
\text { instruction } \\
\text { received }\end{array}$} & Interest & 23 \\
\hline & & Satisfaction & 24 \\
\hline & & Variety & 25 \\
\hline & & Sufficiency & 26 \\
\hline
\end{tabular}




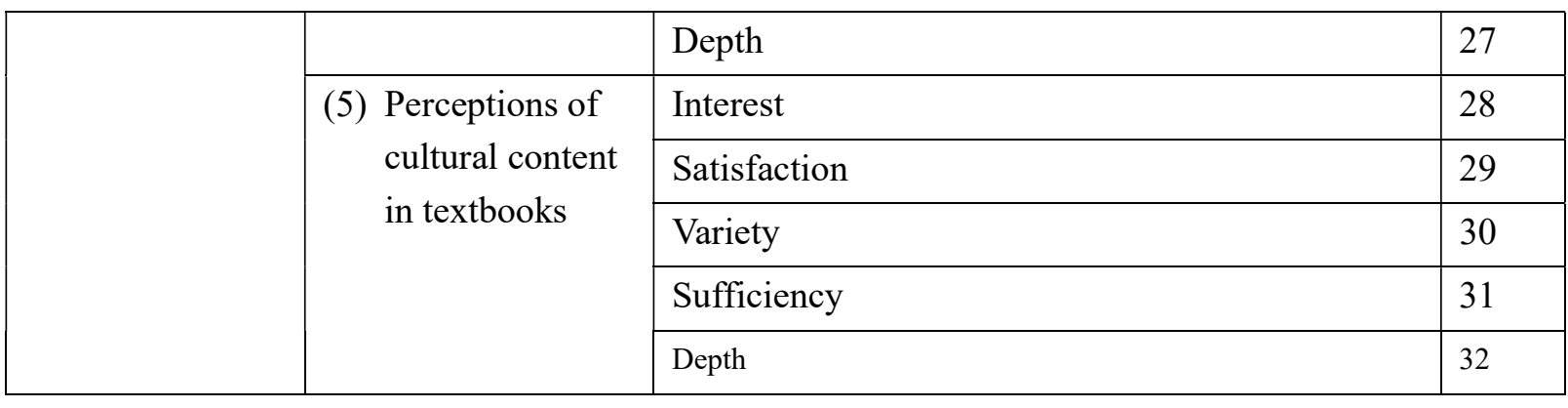

\subsubsection{Interview}

The data collected from the flexible semi-structured interviews, allowing new questions to be brought up in response to interviewee remarks, formed the secondary data source to support the quantitative findings. A series of prearranged questions related directly to the research questions (aspects of the participants' demographic information, thoughts on language and culture, thoughts on English as a lingua franca, current intercultural instruction received and their interests, expectations or suggestions) were asked to elicit the responses to support the quantitative data (Appendix 1). Each interview lasted from 40 to 60 minutes. Interviewees were allowed to respond either in Chinese or English. The contents of each interview were recorded, transcribed and translated into English, with the interviewees' permission, by two language experts.

\subsection{Data Analysis}

To answer the research questions, statistical analysis was conducted for the data collected from the questionnaire survey. To analyze the data collected from the interviews, a qualitative analysis suggested by Miles and Huberman (1994) consisting of three procedures, data reduction, data display and conclusion drawing/verification, was implemented. First, the collected data were carefully read. After that, all statements relating to the research question were identified and each was assigned a code or category. These codes were then noted, and each relevant statement was organized under its appropriate code. Next, using the codes developed, the researcher reread the data to confirm that the concepts and categories accurately represent interview responses and to explore how the concepts and categories were related. Coded data were then categorized into the themes of the questionnaire.

\section{Results}

The percentages for each item in each of the five themes for L1, L2 and L3 are presented in Tables. The last column in the tables shows the sum of the percentage showing agreement and the percentage showing strong agreement, which was used for discussion in the results.

\subsection{Perceptions of language and culture}

As shown in Table 3, item 1 to10 deal with students' perceptions of language and culture, with item 1 relating to interest in culture, items 2 and 3 concerning the relationship of language and culture, items 4 to 7 relating to goals for culture learning, and items 8 to 10 concerning perceived benefits of culture learning. The percentages of the 10 items for each level are presented. 
More than three quarters (77\%) of the L1 participants agreed or strongly agreed that they were interested in culture. More than two thirds (69\%) of the L2 participants also showed such interest. In L3, 53\% of participants agreed or strongly agreed with such interest. When it comes to the relationship of language and culture, the majority of the L1 participants $(90 \%$, $87 \%)$ and the L2 participants $(87 \%, 86 \%)$ agreed or strongly agreed that language and culture are closely related. In L3, approximately $70 \%$ of participants showed such agreement. Regarding goals for culture learning, the majority of the participants, $87 \%-97 \%$ in L1, $86 \%-97 \%$ in L2, and $79 \%-89 \%$ in L3, agreed or strongly agreed with the role of learning culture in understanding others and in communication. As for the perceived benefits of culture learning, $50 \%$ to $74 \%$ of L1 participants, agreed or strongly agreed with the statements regarding enhancing motivation, making learning fun and improving proficiency. The percentages for this ranged from $54 \%$ to $59 \%$ in L2, and from $37 \%$ to $54 \%$ in L1. In general, these percentages revealed that students held a positive perception of language and culture. However, it is noted that the percentages of agreement regarding the perceived benefits of culture learning were relatively lower than for other themes at each level, in particular for item 10. This indicates a somewhat lower level of agreement for the statement that culture learning can improve proficiency.

The findings drawn from the quantitative data were mirrored in students' opinions in the interviews. Here are some examples regarding relationship, goals for culture learning, and benefits.

My English is not good. I always get bad grades. I am interested in knowing about other cultures. But I don't think culture learning can help me do a good job in exams, like TOEIC. (Interview L3S2, 03/23/2018)

Learning a language is learning its culture. When we learn English, we also learn culture. For example, we learn about Christmas, or Thanksgiving in English class. We learn the history, when people celebrate, and how they celebrate these festivals. (Interview L3S4, 03/23/2018)

I learn English because I want to study abroad or get a job in a foreign country in the future. If I know more about different cultures, it will help me survive in a new environment and communicate better with others. (InterveiwL1S1, 03/26/2018)

In high school, we had to read English magazines every month. In every issue, there were always some topics about different places and their values, such as festivals around the world, or differences between east and west. This is how I learned new knowledge about the world. I enjoyed reading them. It was interesting. (Interview L1S4, 03/26/2018) 
Table 3. Perceptions of language and culture

\begin{tabular}{|c|c|c|c|c|c|c|c|c|c|}
\hline $\operatorname{Item}(\mathrm{s})$ & Level & $\mathrm{N}$ & Strongly disagree & Disagree & Slightly disagree & Slightly agree & Agree & Strongly agree & \\
\hline \multirow[t]{3}{*}{ 1. Interest in cutlure } & L1 & 67 & $0 \%$ & $0 \%$ & $3 \%$ & $20 \%$ & $44 \%$ & $33 \%$ & $77 \%$ \\
\hline & L2 & 74 & $0 \%$ & $0 \%$ & $7 \%$ & $24 \%$ & $36 \%$ & $33 \%$ & $69 \%$ \\
\hline & L3 & 69 & $1 \%$ & $1 \%$ & $6 \%$ & $39 \%$ & $43 \%$ & $10 \%$ & $53 \%$ \\
\hline \multirow[t]{3}{*}{ 2. Language and culture closely related } & $\mathrm{L} 1$ & 67 & $0 \%$ & $1 \%$ & $1 \%$ & $7 \%$ & $41 \%$ & $49 \%$ & $90 \%$ \\
\hline & L2 & 74 & $0 \%$ & $0 \%$ & $3 \%$ & $10 \%$ & $34 \%$ & $53 \%$ & $87 \%$ \\
\hline & L3 & 69 & $0 \%$ & $0 \%$ & $4 \%$ & $26 \%$ & $39 \%$ & $31 \%$ & $70 \%$ \\
\hline \multirow[t]{3}{*}{ 3. Culture is important in language leanring } & L1 & 67 & $0 \%$ & $0 \%$ & $1 \%$ & $11 \%$ & $40 \%$ & $47 \%$ & $87 \%$ \\
\hline & L2 & 74 & $0 \%$ & $0 \%$ & $3 \%$ & $11 \%$ & $47 \%$ & $39 \%$ & $86 \%$ \\
\hline & L3 & 69 & $0 \%$ & $0 \%$ & $4 \%$ & $20 \%$ & $51 \%$ & $24 \%$ & $75 \%$ \\
\hline \multirow[t]{3}{*}{ 4,. Culture learning helps gian knowledge } & L1 & 67 & $0 \%$ & $0 \%$ & $0 \%$ & $3 \%$ & $27 \%$ & $70 \%$ & $97 \%$ \\
\hline & L2 & 74 & $0 \%$ & $0 \%$ & $0 \%$ & $10 \%$ & $33 \%$ & $57 \%$ & $90 \%$ \\
\hline & L3 & 69 & $0 \%$ & $0 \%$ & $1 \%$ & $10 \%$ & $50 \%$ & $39 \%$ & $89 \%$ \\
\hline 5. Culture learning helps understand & L1 & 67 & $0 \%$ & $0 \%$ & $1 \%$ & $4 \%$ & $26 \%$ & $69 \%$ & $95 \%$ \\
\hline \multirow[t]{2}{*}{ the differences } & L2 & 74 & $0 \%$ & $0 \%$ & $0 \%$ & $3 \%$ & $41 \%$ & $56 \%$ & $97 \%$ \\
\hline & L3 & 69 & $0 \%$ & $0 \%$ & $3 \%$ & $11 \%$ & $54 \%$ & $31 \%$ & $85 \%$ \\
\hline 6. Culture learning helps develop & L1 & 67 & $0 \%$ & $0 \%$ & $1 \%$ & $11 \%$ & $24 \%$ & $63 \%$ & $87 \%$ \\
\hline \multirow[t]{2}{*}{ positive attitude towards others } & L2 & 74 & $0 \%$ & $0 \%$ & $1 \%$ & $11 \%$ & $36 \%$ & $51 \%$ & $87 \%$ \\
\hline & L3 & 69 & $0 \%$ & $0 \%$ & $3 \%$ & $19 \%$ & $46 \%$ & $33 \%$ & $79 \%$ \\
\hline \multirow[t]{3}{*}{ 7. Culture leanring helps communication } & L1 & 67 & $0 \%$ & $0 \%$ & $0 \%$ & $13 \%$ & $36 \%$ & $51 \%$ & $87 \%$ \\
\hline & L2 & 74 & $0 \%$ & $1 \%$ & $4 \%$ & $9 \%$ & $39 \%$ & $47 \%$ & $86 \%$ \\
\hline & L3 & 69 & $0 \%$ & $0 \%$ & $1 \%$ & $16 \%$ & $51 \%$ & $31 \%$ & $82 \%$ \\
\hline 8. Cut;lure learning can motivate my & L1 & 67 & $0 \%$ & $1 \%$ & $7 \%$ & $23 \%$ & $44 \%$ & $23 \%$ & $67 \%$ \\
\hline \multirow[t]{2}{*}{ learning } & L2 & 74 & $0 \%$ & $1 \%$ & $7 \%$ & $37 \%$ & $36 \%$ & $19 \%$ & $55 \%$ \\
\hline & L3 & 69 & $1 \%$ & $1 \%$ & $7 \%$ & $47 \%$ & $31 \%$ & $11 \%$ & $42 \%$ \\
\hline 9. Culture leanring makes class more & L1 & 67 & $0 \%$ & $0 \%$ & $0 \%$ & $26 \%$ & $41 \%$ & $33 \%$ & $74 \%$ \\
\hline \multirow[t]{2}{*}{ interesting } & L2 & 74 & $0 \%$ & $0 \%$ & $7 \%$ & $34 \%$ & $36 \%$ & $23 \%$ & $59 \%$ \\
\hline & L3 & 69 & $1 \%$ & $3 \%$ & $4 \%$ & $37 \%$ & $43 \%$ & $11 \%$ & $54 \%$ \\
\hline 10. Culture leanring helps improve & L1 & 67 & $1 \%$ & $3 \%$ & $3 \%$ & $43 \%$ & $33 \%$ & $17 \%$ & $50 \%$ \\
\hline \multirow[t]{2}{*}{ English proficiency } & L2 & 74 & $0 \%$ & $0 \%$ & $14 \%$ & $31 \%$ & $34 \%$ & $20 \%$ & $54 \%$ \\
\hline & L3 & 69 & $1 \%$ & $1 \%$ & $14 \%$ & $46 \%$ & $31 \%$ & $6 \%$ & $37 \%$ \\
\hline
\end{tabular}

\subsection{Self-awareness of ELF}

As shown in Table 4, items 11 to 14 deal with the students' attitude toward native-speaker English and types of cultures to learn in the context of English as lingua franca. The percentages showing agreement or strong agreement on native-speaking English (NS) as Standard English were 39\% in L1, 41\% in L2, and 36\% in L3 respectively. As for the cultures to learn, the percentages for learning English-speaking cultures were $43 \%$ in L1, 54\% in L2, and $39 \%$ in L3. The percentages for learning local culture were $26 \%$ in $\mathrm{L} 1,23 \%$ in $\mathrm{L} 2$, and $17 \%$ in L3. In the item of learning foreign cultures, the percentages were $24 \%$ in L1, $27 \%$ in L2, and $23 \%$ in L3. Thus at all three levels, a common tendency towards English-speaking cultures as the priority and local culture as the least desired culture to learn was found.

This finding was also confirmed in the interviews. The interviewees were all asked to rank what culture should be taught in the English class. Among the 13 interviewees, there were 11 interviewees reporting the same result as shown in Table 4: English-speaking cultures as the priority and students' own culture the least important. However, the other two students presented a different result, ranking their own culture as the top choice. According to their explanations, this was a result from their intercultural-contact experience. Take this L1S2 quote for example.

I have a Japanese friend. We communicate with each other in English on Facebook. I didn't know the importance of Taiwanese culture in communication until I met my foreign friend. I 
encountered a lot of barriers when I was trying to express my culture. Therefore, I think learning own culture is important. (Interview L1S2, 03/28/2018)

Table 4. Self-awareness of ELF

\begin{tabular}{|c|c|c|c|c|c|c|c|c|c|}
\hline Item(s) & Level & N & Strongly disagree Disagree & Slightly disagreeSlightly agree & Agree & \multicolumn{2}{|l|}{ Strongly agree } \\
\hline 11. Native-speaking English as & L1 & 67 & $3 \%$ & $6 \%$ & $23 \%$ & $30 \%$ & $23 \%$ & $16 \%$ & $39 \%$ \\
\hline standard English & L2 & 74 & $3 \%$ & $6 \%$ & $11 \%$ & $39 \%$ & $24 \%$ & $17 \%$ & $41 \%$ \\
\hline & L3 & 69 & $4 \%$ & $3 \%$ & $21 \%$ & $36 \%$ & $27 \%$ & $9 \%$ & $36 \%$ \\
\hline 12. English-speaking cultures & L1 & 67 & $0 \%$ & $0 \%$ & $11 \%$ & $46 \%$ & $29 \%$ & $14 \%$ & $43 \%$ \\
\hline should be included & L2 & 74 & $0 \%$ & $1 \%$ & $10 \%$ & $36 \%$ & $36 \%$ & $17 \%$ & $53 \%$ \\
\hline & L3 & 69 & $0 \%$ & $3 \%$ & $10 \%$ & $49 \%$ & $29 \%$ & $10 \%$ & $39 \%$ \\
\hline 13. Local culture should be & L1 & 67 & $3 \%$ & $10 \%$ & $24 \%$ & $37 \%$ & $20 \%$ & $6 \%$ & $26 \%$ \\
\hline included & L2 & 74 & $3 \%$ & $4 \%$ & $29 \%$ & $41 \%$ & $19 \%$ & $4 \%$ & $23 \%$ \\
\hline & L3 & 69 & $1 \%$ & $6 \%$ & $41 \%$ & $34 \%$ & $17 \%$ & $0 \%$ & $17 \%$ \\
\hline 14. Foreign cultures should & L1 & 67 & $4 \%$ & $9 \%$ & $26 \%$ & $37 \%$ & $20 \%$ & $4 \%$ & $24 \%$ \\
\hline be included & L2 & 74 & $1 \%$ & $6 \%$ & $34 \%$ & $31 \%$ & $23 \%$ & $4 \%$ & $27 \%$ \\
\hline & L3 & 69 & $1 \%$ & $6 \%$ & $27 \%$ & $43 \%$ & $17 \%$ & $6 \%$ & $23 \%$ \\
\hline
\end{tabular}

\subsection{Current cultural instruction received in the classroom}

With respect to current cultural instruction received, results are shown in Table 5. Item 15 showed that less than $50 \%$ of the participants from each level agreed or strongly agreed that their teachers stressed the importance of culture learning in class. For items 16 to 18, the percentages of the participants agreeing or strongly agreeing showed that authentic materials were the most widely-used method in each level with $84 \%$ in L1, 48\% in L2, and $49 \%$ in L3. It is noted that for both approaches and assessment, the percentages of agreement for L1 were higher than those for L2 or L3, indicating high-level students received somewhat more cultural instruction. As for the types of culture taught, this is shown in items 20 to 22 in Table 5. The smallest percentages are for item 20, Local culture, with $32 \%$ in L1, 33\% in L2, and $30 \%$ in L3, indicating that the local culture was less mentioned compared to English-speaking or foreign cultures. This ranking corresponded to students' thoughts concerning types of culture they want to learn in mentioned earlier. The implications of these percentages can be elucidated more with the support of the interviews.

One question regarding the percentages of linguistic knowledge and cultural content taught in the class was asked during the interviews. The results showed 11 interview participants reported a focus on linguistic knowledge or grammar with most percentages ranging from $70 \%$ to $90 \%$. Two participants reported $50 \%$ and $60 \%$ of teaching included a cultural dimension. The following were four representative quotes showing to what extent culture is integrated into English teaching.

My teacher teaches the readings in the textbook. Although some readings are about cultural issues, most of the time is spent on vocabulary, explaining sentences and grammar. We do the vocabulary exercise in the textbook as homework. The teaching is very similar to what we did in high school. (Interview L3S4, 03/23/2018)

In high school we read a lot of English magazines. The articles in the magazines usually include many culture-related topics. In college, we only read textbooks. Some topics in the 
textbook are about culture, for example different cultures have different opinions about beauty. (Interview L2S2, 03/23/2018)

Sometimes our teacher uses the videos from YouTube or Ted Talks as supplement supplementary materials related to the topics in the textbook. Or ask us to make a presentation related to the topics in the textbook such as environmental issues, endangered animals, or earthquakes in Taiwan and Japan. (Interview L1S2, 03/23/2018)

This semester our teacher has asked us to do a foreigner interview project. We interviewed foreigners in the night market or at the MRT stations. It is a group project. We have to record or video tape our interview and make a presentation about our interview in class. (Interview L1S3, $03 / 23 / 2018$ )

Table 5. Current cultural instruction received in the classroom

\begin{tabular}{|c|c|c|c|c|c|c|c|c|c|}
\hline Item(s) & Level & $\mathrm{N}$ & Strongly disagree & Disagree & Slightly disagree & Slightly agree & Agree & Strongly agree & \\
\hline \multirow[t]{3}{*}{ 15. Teacher attention to culture } & L1 & 67 & $0 \%$ & $0 \%$ & $11 \%$ & $47 \%$ & $37 \%$ & $4 \%$ & $41 \%$ \\
\hline & L2 & 74 & $1 \%$ & $4 \%$ & $16 \%$ & $51 \%$ & $21 \%$ & $6 \%$ & $27 \%$ \\
\hline & L3 & 69 & $1 \%$ & $7 \%$ & $14 \%$ & $39 \%$ & $34 \%$ & $4 \%$ & $38 \%$ \\
\hline \multirow[t]{3}{*}{ 16. Comparison appraoch } & L1 & 67 & $0 \%$ & $1 \%$ & $16 \%$ & $39 \%$ & $34 \%$ & $10 \%$ & $44 \%$ \\
\hline & L2 & 74 & $3 \%$ & $3 \%$ & $26 \%$ & $43 \%$ & $17 \%$ & $9 \%$ & $26 \%$ \\
\hline & L3 & 69 & $1 \%$ & $6 \%$ & $21 \%$ & $41 \%$ & $23 \%$ & $7 \%$ & $30 \%$ \\
\hline \multirow[t]{3}{*}{ 17. Intercultural activities } & L1 & 67 & $0 \%$ & $1 \%$ & $9 \%$ & $36 \%$ & $43 \%$ & $11 \%$ & $54 \%$ \\
\hline & L2 & 74 & $3 \%$ & $3 \%$ & $21 \%$ & $41 \%$ & $24 \%$ & $7 \%$ & $31 \%$ \\
\hline & L3 & 69 & $1 \%$ & $4 \%$ & $21 \%$ & $30 \%$ & $36 \%$ & $7 \%$ & $43 \%$ \\
\hline \multirow[t]{3}{*}{ 18. Authentic materials } & L1 & 67 & $0 \%$ & $0 \%$ & $1 \%$ & $14 \%$ & $44 \%$ & $40 \%$ & $84 \%$ \\
\hline & L2 & 74 & $1 \%$ & $3 \%$ & $13 \%$ & $34 \%$ & $34 \%$ & $14 \%$ & $48 \%$ \\
\hline & L3 & 69 & $0 \%$ & $7 \%$ & $9 \%$ & $36 \%$ & $40 \%$ & $9 \%$ & $49 \%$ \\
\hline \multirow[t]{3}{*}{ 19. Assessment } & L1 & 67 & $1 \%$ & $0 \%$ & $10 \%$ & $30 \%$ & $37 \%$ & $21 \%$ & $58 \%$ \\
\hline & L2 & 74 & $1 \%$ & $4 \%$ & $14 \%$ & $43 \%$ & $24 \%$ & $13 \%$ & $37 \%$ \\
\hline & L3 & 69 & $0 \%$ & $9 \%$ & $19 \%$ & $34 \%$ & $30 \%$ & $9 \%$ & $39 \%$ \\
\hline \multirow[t]{3}{*}{ 20. Including local culture } & L1 & 67 & $0 \%$ & $7 \%$ & $20 \%$ & $41 \%$ & $26 \%$ & $6 \%$ & $32 \%$ \\
\hline & L2 & 74 & $3 \%$ & $4 \%$ & $29 \%$ & $31 \%$ & $23 \%$ & $10 \%$ & $33 \%$ \\
\hline & L3 & 69 & $0 \%$ & $11 \%$ & $21 \%$ & $37 \%$ & $26 \%$ & $4 \%$ & $30 \%$ \\
\hline 21. Including English-speaking & L1 & 67 & $0 \%$ & $0 \%$ & $7 \%$ & $36 \%$ & $39 \%$ & $19 \%$ & $58 \%$ \\
\hline \multirow[t]{2}{*}{ cultures } & L2 & 74 & $1 \%$ & $3 \%$ & $16 \%$ & $31 \%$ & $39 \%$ & $10 \%$ & $49 \%$ \\
\hline & L3 & 69 & $1 \%$ & $3 \%$ & $19 \%$ & $43 \%$ & $33 \%$ & $1 \%$ & $34 \%$ \\
\hline \multirow[t]{3}{*}{ 22. Including foreign cultures } & L1 & 67 & $0 \%$ & $1 \%$ & $10 \%$ & $36 \%$ & $39 \%$ & $14 \%$ & $53 \%$ \\
\hline & L2 & 74 & $1 \%$ & $1 \%$ & $21 \%$ & $40 \%$ & $31 \%$ & $4 \%$ & $35 \%$ \\
\hline & $\underline{\mathrm{L} 3}$ & $\underline{69}$ & $1 \%$ & $4 \%$ & $23 \%$ & $36 \%$ & $29 \%$ & $7 \%$ & $36 \%$ \\
\hline
\end{tabular}

\subsection{Perceptions of cultural instruction received}

Students' perceptions of cultural instruction received were discussed in terms of interest, satisfaction, variety, sufficiency and depth. As shown in Table 6, the percentages of students who agreed or strongly agreed with the criteria in L1 ranged from $48 \%$ to $68 \%, 29 \%$ to $37 \%$ in L2, and $28 \%$ to $43 \%$ in L3. It should be noted that less than half of the participants agreed or strongly agreed with the statements in both L2 and L3, indicating not many students of L2 and L3 agreed or strongly agreed that the criteria for instruction were met. The following quotes from L2S3 and L3S1 could help explain what the data implied.

When it comes to cultural instruction, I prefer exploring the topic with group members to reading the information in the textbook. If we can choose what we are interested in and find 
what we would like to share with the class, it is more interesting. (Interview L2S3, 03/29/2018)

Our teacher mainly teaches the readings in the textbook and asks us to do the exercise after each reading. The teacher gives us a vocabulary list to help us prepare for the quiz or exams. There is not much content about cultures and I don't think my teacher can teach culture. (Interview L3S1, 03/23/2018)

Table 6. Perceptions of cultural instruction received

\begin{tabular}{|l|c|c|c|c|c|c|c|c|c|}
\hline Item(s) & Level & N & Strongly disagree & Disagree & Slightly disagree & Slightly agree & Agree & Strongly agree \\
\hline 23. Interest & L1 & 67 & $0 \%$ & $1 \%$ & $11 \%$ & $34 \%$ & $33 \%$ & $20 \%$ & $53 \%$ \\
\hline & L2 & 74 & $4 \%$ & $3 \%$ & $14 \%$ & $47 \%$ & $23 \%$ & $9 \%$ & $32 \%$ \\
\hline & L3 & 69 & $3 \%$ & $7 \%$ & $23 \%$ & $34 \%$ & $27 \%$ & $6 \%$ & $33 \%$ \\
\hline & 24 & 67 & $0 \%$ & $0 \%$ & $10 \%$ & $23 \%$ & $39 \%$ & $29 \%$ & $68 \%$ \\
\hline & L2 & 74 & $1 \%$ & $7 \%$ & $10 \%$ & $44 \%$ & $27 \%$ & $10 \%$ & $37 \%$ \\
\hline & L3 & 69 & $3 \%$ & $6 \%$ & $11 \%$ & $41 \%$ & $30 \%$ & $9 \%$ & $39 \%$ \\
\hline 25. Variety & L1 & 67 & $0 \%$ & $0 \%$ & $9 \%$ & $26 \%$ & $39 \%$ & $29 \%$ & $68 \%$ \\
\hline & L2 & 74 & $3 \%$ & $7 \%$ & $11 \%$ & $41 \%$ & $21 \%$ & $10 \%$ & $31 \%$ \\
\hline & L3 & 69 & $1 \%$ & $6 \%$ & $14 \%$ & $36 \%$ & $33 \%$ & $10 \%$ & $43 \%$ \\
\hline 26. Sufficiency & L1 & 67 & $1 \%$ & $0 \%$ & $11 \%$ & $31 \%$ & $33 \%$ & $23 \%$ & $56 \%$ \\
\hline & L2 & 74 & $3 \%$ & $6 \%$ & $17 \%$ & $44 \%$ & $21 \%$ & $9 \%$ & $30 \%$ \\
\hline & L3 & 69 & $4 \%$ & $4 \%$ & $19 \%$ & $36 \%$ & $30 \%$ & $7 \%$ & $37 \%$ \\
\hline 27. Depth & L1 & 67 & $0 \%$ & $0 \%$ & $11 \%$ & $41 \%$ & $29 \%$ & $19 \%$ & $48 \%$ \\
\hline & L2 & 74 & $4 \%$ & $7 \%$ & $24 \%$ & $36 \%$ & $20 \%$ & $9 \%$ & $29 \%$ \\
\hline & L3 & 69 & $1 \%$ & $6 \%$ & $26 \%$ & $39 \%$ & $24 \%$ & $4 \%$ & $28 \%$ \\
\hline
\end{tabular}

\subsection{Perceptions of cultural content in textbooks}

Items 28 to 32 dealt with students' perceptions of cultural content in current English textbooks in terms of interest, satisfaction, variety, sufficiency and depth. As shown in Table 7 , the percentages showing students who agreed or strongly agreed with the five criteria ranged from $39 \%$ to $57 \%$ in L1, $24 \%$ to $40 \%$ in L2, and $20 \%$ to $24 \%$ in L3. It should be noted that compared to the percentages regarding perception of instruction received shown in Table 5 , the percentages of the five criteria in every level were much lower, indicating much fewer students had positive attitudes towards the textbooks in use. When comparing item 1, the numbers of students showing interest in culture, and item 28, students showing interest in cultural content in textbooks, we can see student responses are very different. These figures are $77 \%$ vs. $39 \%$ in L1, $69 \%$ vs. $30 \%$ in L2, vs. $53 \%$ and $20 \%$ in L3. More insightful views regarding textbooks were revealed in the following interview exerts.

The cultural information in the textbooks is so factual. Actually we can gain the same knowledge from the internet or by using Google. I prefer to learn cultural knowledge through real intercultural contact, like talking to foreigners. Textbooks are too boring. For example, I joined a club called Global Papago held in National Taiwan Normal University, where many foreign students studying in Taiwan tell us about their cultures. (Interview L3S5, 03/29/2018)

The content in the textbook is not as varied as the content in the magazines which include many current issues and interesting topics. Some topics in the textbook are distant from our life. They don't help us improve our communication ability. A focus on English for everyday 
life is more practical. The test about the textbook is meaningless. (Interview L1S2, 03/29/2018)

Table 7. Perceptions of cultural content in textbooks

\begin{tabular}{|l|c|c|c|c|c|c|c|c|c|}
\hline Item(s) & Level & $\mathrm{N}$ & Strongly disagree & Disagree & Slightly disagree & Slightly agree & Agree & Strongly agree & \\
\hline 28. Interest & L1 & 67 & $0 \%$ & $3 \%$ & $11 \%$ & $41 \%$ & $30 \%$ & $14 \%$ & $44 \%$ \\
\hline & L2 & 74 & $1 \%$ & $9 \%$ & $26 \%$ & $39 \%$ & $16 \%$ & $10 \%$ & $26 \%$ \\
\hline & L3 & 69 & $6 \%$ & $7 \%$ & $27 \%$ & $39 \%$ & $19 \%$ & $3 \%$ & $22 \%$ \\
\hline 29. Satisfaction & L1 & 67 & $0 \%$ & $1 \%$ & $20 \%$ & $36 \%$ & $30 \%$ & $13 \%$ & $43 \%$ \\
\hline & L2 & 74 & $0 \%$ & $7 \%$ & $23 \%$ & $46 \%$ & $14 \%$ & $10 \%$ & $24 \%$ \\
\hline & L3 & 69 & $7 \%$ & $6 \%$ & $29 \%$ & $37 \%$ & $19 \%$ & $3 \%$ & $22 \%$ \\
\hline 30. Variety & L1 & 67 & $1 \%$ & $1 \%$ & $13 \%$ & $27 \%$ & $37 \%$ & $20 \%$ & $57 \%$ \\
\hline & L2 & 74 & $0 \%$ & $4 \%$ & $17 \%$ & $39 \%$ & $27 \%$ & $13 \%$ & $40 \%$ \\
\hline & L3 & 69 & $4 \%$ & $7 \%$ & $17 \%$ & $47 \%$ & $20 \%$ & $4 \%$ & $24 \%$ \\
\hline 31. Sufficiency & L1 & 67 & $1 \%$ & $3 \%$ & $13 \%$ & $34 \%$ & $36 \%$ & $13 \%$ & $49 \%$ \\
\hline & L2 & 74 & $1 \%$ & $4 \%$ & $26 \%$ & $37 \%$ & $23 \%$ & $9 \%$ & $32 \%$ \\
\hline & L3 & 69 & $3 \%$ & $10 \%$ & $30 \%$ & $34 \%$ & $20 \%$ & $3 \%$ & $23 \%$ \\
\hline 32. Depth & L1 & 67 & $0 \%$ & $1 \%$ & $26 \%$ & $34 \%$ & $29 \%$ & $10 \%$ & $39 \%$ \\
\hline & L2 & 74 & $0 \%$ & $9 \%$ & $26 \%$ & $36 \%$ & $21 \%$ & $9 \%$ & $30 \%$ \\
\hline & L3 & 69 & $4 \%$ & $7 \%$ & $37 \%$ & $31 \%$ & $17 \%$ & $3 \%$ & $20 \%$ \\
\hline
\end{tabular}

\section{Discussion and Conclusion}

\subsection{Discussion of findings}

This study explored student perspectives on culture and language teaching in EFL in one university, in which students were placed in three levels for the course of Freshman English. The intercultural approach is currently receiving much attention in ELT, but based on the results of this study, there are a number of issues to be concerned over concerning the implementation of ELT in the classroom.

First, the results showed that, in general, most students from three different levels of English proficiency held a very positive belief of the importance of culture in language learning. However, it is worth noting that the percentage of students agreeing or strongly agreeing that culture learning can improve proficiency is comparatively lower than other benefits of culture learning. Take the low-level participants for example: the percentage is only $37 \%$, less than half of the participants. This seems to imply that most students lack the perception that viewing culture is a salient skill contributing to the success of language learning. Traditionally, four skills, listening, speaking, reading and writing, contribute to the language ability measured by exams or language tests. For many Taiwanese students, especially high school students, English is treated as a subject rather than a language. Students do not use it often outside the classroom or for real communication, but take a lot of English exams in school. In such a test-oriented learning context, it is not hard to understand why they may think that culture learning has no relation with improving proficiency as displayed in the results of the all-important tests, even though they show interest in culture learning.

The second concern is the issue of what types of cultures should be learnt or taught in classrooms. The results from student perceptions and the instruction received both showed that English-speaking cultures generally remain a focus. Their own culture is less desired and 
less taught. This finding was also supported by most interviews, except for those who had intercultural experience with a better understanding of the importance of own culture understanding. This might not be a surprise due to the fact that English-speaking cultures have long been regarded as the mainstream in ELT. However, from the ELF perspective, this unquestionably demonstrates that the traditional NS norm-based view is still the dominant perspective among students in this study. However, this perspective will not help fulfill English learners' needs as users of ELF for intercultural communication in a globalized world. After all, intercultural competence begins with a reasonable understanding of ourselves.

Another significant finding is that, in general, the cultural dimension is more or less integrated into all three different levels of proficiency, and the students receive mainly textbook-based instruction. However, the interview data reveals teachers with high level students use more authentic materials or student-centered, project-based activities to facilitate the students' learning, i.e., an intercultural-based approach is more used. In contrast, in low-level classes, intercultural instruction tends to be more textbook-based with a focus on grammar, vocabulary, and sentences. This may explain the reason why fewer students from the low level agreed or strongly agreed with the benefits of culture learning. A number of ELT English textbooks have a cultural syllabus with room for a culture note or cultural corner to help students explore life in different parts of world. Moreover, in light of English as a lingua franca (ELF) and the call for the development of cultural awareness, cultural-related topics are more or less included in recent English textbooks. However, the concern with such resources is how to teach or raise cultural awareness. The methodology matters. As Luo's (2017) study on textbooks concerning content and pedagogy from the perspective of ELF showed, teachers' treatment of the textbooks was not ELF-oriented when taking into account the student level. Thus including more culture teaching in textbooks is not effective unless teaching methodologies change to utilize this effectively. This also leads to another frequently asked question: Do students need to reach a certain level of English proficiency before they begin looking at culture, and if so what level should be appropriate?

With respect to students' perception of the cultural instruction received, the percentages of both L2 participants and L3 participants showing agreement or strong agreement with the statements in terms of interest, satisfaction, variety, sufficiency and depth were less than $50 \%$. A further significant finding is there is a discrepancy between what students are interested in and what is actually presented in the English class. This discrepancy corresponded to the finding in Chen's study in 2011. These results point to serious issues with the current state of culture learning in English classrooms, especially for lower level students.

Finally, the same concerns were also revealed in the perception of the cultural content in the current textbooks. A disparity was also found between students showing interest in culture learning and their interest in cultural contents in textbooks, with the content clearly not meeting students' expectations. Due to the use of the mainly textbook-based instruction in Taiwan, this less than positive attitude towards the textbook in use is likely to affect students' learning negatively. 


\subsection{Pedagogical suggestions}

Based on the above discussion, some pedagogical suggestions can be made for syllabus designers and materials developers in terms of cultural contents in EFL contexts and intercultural-based approaches. These suggestions are important since many teachers rely heavily on the use of ELT textbooks in the classroom, and thus textbook writers must lead the way to facilitate the development of cultural awareness.

First, the role of local culture cannot be overlooked in the context of English as lingua franca. As Kramsch (1993) states, language teaching should include "a reflection both on the target and on the native culture." Robinson (1998) also suggests that "cultural understanding involves a synthesis between the learner's home culture, the target cultural input and the learner as an individual." Language learners learn about other cultures and their own culture at the same time, through a process of comparison and contrast. Therefore, developing ELF-oriented materials including both students' own culture and other cultures would facilitate teaching to meet the goal of preparing students to be ELF users. Textbook developers and teachers are wise to take into account ELF attributes, such as including a more diverse range of cultures and activities that help learners to use ELF. In addition, they should also relate English learning to learners' real life experiences and encourage learners to relate information concerning their own countries and localities with other countries and cultures. Therefore, they should focus less on simply presenting simple cultural facts in readings, and more on activities that promote learning little c cultural elements, i.e., cultural perspectives rather than products or practices of big $\mathrm{C}$ culture. This would involve learners working their way up in understanding culture through worksheets and other assignments, enhancing their knowledge of other cultures, their own culture and language skills in an interesting and informative way. Understanding another's customs and traditions and comparing and contrasting that with one's own can lead to a better understanding of world cultures, and enhance intercultural communication. This would serve to encourage more student engagement for discussion and enable students to realize the importance of their own culture in intercultural communication. In addition, videos based on critical incident methodology which highlights key areas of misunderstanding between cultures would be ideal materials to teach cultural awareness.

Second, while culture learning in general has been integrated into classes, it is still being held back by an exam-based mentality, and further work is required to develop an ELF perspective among teachers and students in Taiwan, and that more intercultural contact can help with both of these. The interview results reveal such impact of intercultural contact on students' use of intercultural communication strategies and their awareness of ELF. However, most students lack such experiential opportunities. Most learning is limited to the textbooks. Implementing productive activities or projects allowing opportunities to use English outside the classroom should be valued more in the curriculum or syllabus design and in evaluation. Thanks to the promotion of international education, the source of teaching materials is becoming more diverse. Using such material that is available and integrating it into teaching can make learning different and create a stronger sense of being an ELF user. For example, a task asking student to make a video to introduce their campus in English can be modified to one 
with a more communicative purpose. Teachers can invite a few foreign students on campus to rate the videos and come to the classroom to give comments so that students can have the chance to use English for real interaction.

Third, while language teachers are making efforts to improve lower-level students' linguistic proficiency, cultural proficiency is usually neglected because the level of learners is usually considered as an impediment to implementing ELF approaches in the classroom. However, limited English should not be a barrier for intercultural communication (IC) (Nerriere \& Hon, 2009). Many teachers might ask the question: How can we move from the linguistic to the intercultural? The answer is by designing activities following the guide of using both proficiency-based approaches and intercultural-based approaches simultaneously. Take a topic of how to spend my weekend for example. The proficiency-based approach leads students to learn types of activities, or expression such as 'like to do' or 'dislike to do'. At the same time, the intercultural-based approach can continue a further discussion on comparing seasonal sports or young peoples' activities in other cultures to stir students' interest and to raise their cultural awareness. To advance this practice, the author suggests teachers participate in conferences, workshops, or training programs for professional development regarding intercultural approaches to improve their professional knowledge, competence, skill, and effectiveness.

\subsection{Conclusion}

This study explored student perspectives on culture and language teaching in EFL through a questionnaire survey and interviews. Students were found generally to have a positive view of culture learning in EFL classes, but doubted its efficacy in helping develop their English skills, possibly due to the exam-centric view of education prevalent in Taiwan. Further, although students generally appreciate cultural content, they still tend towards a native-speaker centric view of culture, rather than one that embraces the perspective of English as a Lingua Franca. Finally, students viewed the actual cultural content in both classes and textbooks as being problematic, focusing on fact-based instruction rather than embracing topics and ideas they were interested in and could develop. The author also discussed pedagogical implications that were drawn from these findings. Recommendations were made concerning the inclusion of more topics relating to local culture, more opportunities for students to engage in authentic intercultural communication, and more attention to culture learning for low-level language learners. It is hoped that this discussion will help in the future development of intercultural-based approaches for syllabus designers, teachers, and materials developers, with the goal of helping develop leaners as effective users of English as a Lingua Franca in world under transformation by globalization.

\section{References}

Alptekin, C. (2002). Towards intercultural communicative competence in ELT. ELT Journal, 56(1), 57-64. https://doi.org/10.1093/elt/56.1.57

Barnes-Karol, G., \& Broner, M. (2010). Using images as springboards to teach culturalperspectives in light of the ideals of the MLA report. Foreign Language Annals, 43, 
422-445. https://doi.org/10.1111/j.1944-9720.2010.01091.x

Brown, H. D. (2001). Teaching by principles: An interactive approach to language pedagogy $\left(2^{\text {nd }} e d.\right)$. White Plains, NY: Longman.

Byram, M. (1997). Teaching and Assessing Intercultural Communicative Competence. Clevedon: Multilingual Matters.

Byram. M. (2009). Intercultural competence in foreign languages. In D. Deardorff(Ed.), The sage handbook of intercultural competence (pp.321-332). Thousand Oaks, CA: Sage.

Byram, M. \& Morgan, C. (1994). Teaching-and-learning: Language-and-culture. Clevedon, UK: Multilingual Matters Ltd.

Chang, S. (2004). Integrating culture with English language learning: Some ideas from a survey of the high school attendants at the 2002 NTNU English camp. English Teaching \&Learning, 28(4), 45-66.

Chao, T. C. (2009). Understanding University English Learners' Intercultural Communication Competence: Related Studies and Curriculum Suggestions. Studies in International Cultures, 5(2), 49-86.

Chen, M. J. (2011). Analysis of the Cultural Content in Senior High School English Textbooks in Taiwan. Unpublished Master's Thesis. National Taiwan Normal University.

Cheng, C. M. (2012). The influence of college EFL teachers' understandings of intercultural competence on their self-reported pedagogical practices in Taiwan. English Teaching: Practice and Critique, 11(1), 164-182.

Cheng, C. W. (2006). A study of the Teaching of Holiday Culture across Different Grade Levels in English Class in Municipal Elementary Schools in Taipei City. Master thesis, National Taipei University of Education, Taipei, Taiwan.

Chung, J. C., \& Chow, S. M. K. (2004). Promoting student learning through a student-centered problem-based learning subject curriculum. Innovations in Education and Teaching International, 41(2), 157-168.

Clark, C. \& Peterson, P. (1986). Teachers' thoughts process. In M.C. Wittrock (Ed.), Second handbook of research on teaching. New York: MacMillan.

Clark, C.\& Yinger, P. (1987). Exploring teacher thinking. IN J. Calderhead (Ed.). Teacher planning. London: Cassell.

Garrett-Rucks, P. (2016). Intercultural Competence in Instructed Language Learning Bridging Theory and Practice. Information Age Pub Inc.

Ho, M. C. (1998). Culture studies and motivation in foreign and second language learning in Taiwan. Language, Culture and Curriculum, 11(2), 162-182. https://doi.org/10.1080/07908319808666548

Ke, I.-C. (2010). Globalization and global English: Panacea or poison for ELT in Taiwan? Taiwan Journal of TESOL, 7(1), 1-27. 
Kramsch, C. (1993). Context and culture in language teaching. Oxford: Oxford University Press.

Lai, C. H. (2006). A Survey of Taoyuan Elementary School English Teachers' Opinions on Teaching American Culture in the English Class. Master Thesis, National Taipei University of Education, Taipei, Taiwan.

Liddicoat, A. (2011). Language teaching and learning from an intercultural perspective, In E. Hinkel (Ed), Handbook of research in second language teaching and learning, 2, 837-855. New York: Routledge.

Lin, W. (2004). A Study on Cross-cultural Barriers in Reading of English. Asia EFL Journal, Article 3, Retrieved June 19, 2007, from http://Asian-efl-journal. com.june_04_wl.php

Luo, W. H. (2017). A study of internationally-published English textbooks from The perspective of English as a Lingua Franca concerning content and pedagogy. Journal ofTextbook Research. 10 (2), 133-159.

McKay, S. L. (2002). Teaching English as an international language. Oxford: Oxford University Press.

Miles, M. B., \& Huberman, A. M. (1994). Qualitative data analysis: A coursebook of new methods. Newbury Park, CA: Sage.

Nerriere, J. P., \& Hon, D. (2009). Globish The World Over. International Globish Institute.

Robinson, G. L. N. (1988) Crosscultural Understanding. Hertfordshire, UK Prentice Hall International Ltd.

Sercu, L. (2006). The foreign language and intercultural competence teacher: The acquisition of a new professional identity. Intercultural Education, 17, 55-72. https://doi.org/10.1080/14675980500502321

Stapleton, P. (2000). Culture's Role in TEFL. An Attitude Survey in Japan. Language, Culture and Curriculum.13(3), 291-305. https://doi.org/10.1080/07908310008666605

Sung, D., \& Chen, P. W. (2008). University students' viewpoints toward incorporating English-speaking cultures into English learning. Proceedings of 2008 NUTN Conference on Innovative Approaches to the Teaching of English: A Collection of Articles on English Teaching and Learning, Tainan, Taiwan, 19-28.

Sung, D., \& Chen, P. W. (2009). Incorporating English-language cultures into English learning: Viewpoints from university English faculty in Taiwan. The International Journal ofLearning, 16(3), 301-313. https://doi.org/10.18848/1447-9494/CGP/v16i03/46171

Sung, D. \& Chen, Y. P. (2014). Integrating American Culture into English Teaching Investigating the Effect on Taiwanese University Students' Learning Motivation. Journal of Applied English, 7, 97-116.

Tavares, R., \& Cavalcanti, I. (1996). Developing cultural awareness in EFL Classrooms. English Forum, 34(3). 


\section{I Macrothink}

Tsai, Y. (2016). Promoting the cultural dimension in EFL teaching: A turning point for English Education in Taiwan. In Wen-Chuan Lin \& Michael Byram (ed.), New Approaches to English Language and Education in Taiwan: Cultural and Intercultural Perspectives. Tung Hua Book Co., Ltd.

$\mathrm{Wu}, \mathrm{C}$. H. (2015). Exploring practices for teaching intercultural communication: A case study of three teachers at a college in Taiwan. In Michal B. Paradowski (ed.), Productive Foreign Language Skills for an Intercultural World-A Guide (not only) for Teachers. Peter Lang.

Yang. C. C. (2004). Chiayi \& Tainan elementary school English teachers' opinions survey toward culture teaching. Unpublished master's thesis, Nan-Tai Science University.

Yo, W. J. (2007). Teaching Culture in EFL Classrooms: Taipei City Elementary English Teachers' View and Practice of Culture. Unpublished master's thesis, National Taipei University of Education.

Young, T. J., \& Sachdev, I. (2011). Intercultural communicative competence: Exploring English language teachers' beliefs and practices. Language Awareness, 20(2), 81-98. https://doi.org/10.1080/09658416.2010.540328

\section{Appendix}

Appendix 1. Protocol Interview Questions

1. What are your' self-perceived goals for English learning?

2. What are your understandings of culture and language? (language learning/role of culture in language learning)

3. What are your attitudes towards English as International Language (preferred varieties of English, NS/NNS teachers and cultural materials)? Why?

4. Between language knowledge and culture learning, which do you receive more in your class? Are you satisfied with this proportion? Why or why not?

5. Please describe details of cultural instruction received in the classroom (methods, activities, materials, topics...)

6. What are your feelings or reactions of cultural instruction received?

7. What are your expectations or suggestions for language and culture learning? (instruction, learning materials, assessment)

\section{Copyright Disclaimer}

Copyright for this article is retained by the author(s), with first publication rights granted to the journal.

This is an open-access article distributed under the terms and conditions of the Creative Commons Attribution license (http://creativecommons.org/licenses/by/3.0/). 